ISSN 1678-3921

Journal homepage: www.embrapa.br/pab

For manuscript submission and journal contents, access: www.scielo.br/pab

\section{Relationship between heterosis, weight gain, and body measurements of Nellore and Charolais calves}

\begin{abstract}
The objective of this work was to assess the effect of genetic group and heterosis on the relationship between body weight and morphometric measurements, in purebred and crossbred animals from the second (G2) and third (G3) generations of Nellore and Charolais calves. Body weight (BW), average daily weight gain (ADG), foreleg circumference (FC), thoracic girth (TG), body length (BL), and croup height $(\mathrm{CH})$ were measured at birth and at 63,210 , and 365 days of age in animals from G2 and G3. Charolais animals were superior to Nellore ones for gains BW, ADG, BL, and TG, as well as for the ratio between $\mathrm{BW}$ gain and $\mathrm{CH}$ gain; Nellore animals were superior for $\mathrm{CH}$ gains. Crossbred animals of both generations were superior to the purebred animals for gains of $\mathrm{BW}, \mathrm{BL}$, and $\mathrm{CH}$. In $\mathrm{G} 2$, the predominance of Charolais genes resulted in greater gains of BW, ADG, FC, and TG. The G3 animals were superior to the purebred animals for ADG, FC, and TG. No differences were found for the ratio between gains of weight and morphometric measurements. Heterosis and complementarity are apparent for weight and body measurements of crossbred calves from rotational crossings.
\end{abstract}

Index terms: biometry, beef calves, complementarity, crossbred, growth.

\section{Relação entre heterose, ganho de peso e medidas corporais de bezerros Nelore e Charolês}

Resumo - O objetivo deste trabalho foi avaliar o efeito do grupo genético e da heterose na relação entre peso corporal e medidas morfométricas, em bezerros puros e mestiços das raças Nelore e Charolesa de segunda (G2) e terceira (G3) gerações. Peso corporal (PC), ganho de peso médio diário (GMD), circunferência da perna dianteira (CPD), circunferência torácica (CT), comprimento corporal (CC) e altura da garupa (AG) foram medidos ao nascimento e aos 63, 210 e 365 dias de idade, nos animais de G2 e G3. Os animais da raça Charolesa foram superiores aos da Nelore quanto aos ganhos de PC, GMD, CC e CT, e para a razão entre o ganho de PC e o de AG; os animais Nelore foram superiores quanto aos ganhos de AG. Animais mestiços de ambas as gerações foram superiores aos animais puros quanto aos ganhos de PC, CC e AG. Na G2, a predominância dos genes da raça Charolesa resultou em maiores ganhos de PC, GMD, CPD e CT. Os animais da G3 foram superiores aos puros quanto a GMD, CPD e CT. Não se encontraram diferenças na proporção entre os ganhos nas medidas de peso e morfometria. Heterose e complementaridade são aparentes para as medidas de peso e corporais de bezerros mestiços de cruzamentos rotacionais.

Termos para indexação: biometria, bezerros de corte, complementaridade, mestiço, crescimento. 


\section{Introduction}

Body weight is the main criterion of the selection and management (feeding and health) of animals (Lucila Sobrinho et al., 2013). However, morphometric measurements can also be reliable, as they are less subject to temporary effects - such as the filling out of the gastrointestinal tract, when measuring body weight -, and they are more accurate than subjective methods, such as visual scores (Lesosky et al., 2013). However, there is a large variation of performance and body growth among breeds of beef cattle (Menezes et al., 2005). The crossing of Taurine breeds with Zebu cattle is widely used to increase the production of bovine herds by the exploration of the generated heteroses, with variations of performance between the generations of crossbreeds (Pacheco et al., 2014; Vaz et al., 2016).

Morphometric measurements can be taken with the aid of a tape measure, at low cost, good precision, consistency and high repeatability, with a low-standard deviation for the average values (Choy et al., 2017).

Morphometric measurements can be used as a selection criterion based on animal growth (Lesosky et al., 2013) and are useful to understand this growth (Choy et al., 2017), when associating them with body weight. The result is a better description of individuals and populations, indicating bodily changes over time. Further, these measurements are indirect predictors of performance and productive longevity (Lee \& Kim, 2010) and can be used to estimate animal weight and conformation (Fernandes et al., 2010; Wangchuk et al., 2018).

Thoracic girth and croup height are positively correlated with body weight (Vanvanhossou et al., 2018). Methods to estimate the weight of cattle were developed using equations derived from morphometric body measurements (Gunawan \& Jakaria, 2010). However, due to growth variations between races, there may be differences of precision of the models for the relationship between weight gain and increases of body measurements. As similar behavior occurs between the increase of measurements and the increase of body weight of Bos taurus and Bos indicus cattle and their crosses, it is possible to work on the creation of a weight-determination model through the increase of body measurements. The heterosis generated by crossing Charolais and Nellore animals increases the productivity of the herds (Favero et al.,
2019). However, all measured heteroses generally originate in characteristics that are very dependent on the breeding conditions of the animals, differently from body measurements which are less susceptible to variations in the environment (Mendonça et al., 2019).

The combination of body measurements and weight are of interest as predictors to the beef industry, as it allow of the determination of more productive animals (Vaz et al., 2016), with a higher proportion of heavier prime cuts in the carcass (Cardoso et al., 2020) and even a greater degree of fat (Sakamoto et al., 2014; Huerta-Leidenz et al., 2018).

The objective of this work was to evaluate the effect of genetic group and heterosis on the relationship between weight and morphometric measurements, in purebred and crossbred Nellore and Charolais calves from second and third generations, in continuous alternating crossing.

\section{Materials and methods}

The study was carried out at the Universidade Federal de Santa Maria, located in the Depressão Central region (at $29^{\circ} 43^{\prime} \mathrm{S}$ and $53^{\circ} 42^{\prime} \mathrm{W}$, at $95 \mathrm{~m}$ altitude), in the state of Rio Grande do Sul, Brazil. According to the classification of Köppen-Geiger, the climate in the region is humid subtropical (cfa) (Moreno, 1961).

A total of 159 calves was used, from which 29 Charolais (C), 22 Nellore $(\mathrm{N})$, and animals from the second generation (G2) $(21-3 / 4 \mathrm{C} 1 / 4 \mathrm{~N}$, and $9-3 / 4 \mathrm{~N}$ $1 / 4 \mathrm{C})$, and third generation (G3) $(44-5 / 8 \mathrm{C} 3 / 8 \mathrm{~N}$, and $34-5 / 8 \mathrm{~N} \mathrm{3/8C)}$. All births occurred during the same calving season, and the animals were kept under the same conditions of health and nutritional management for 365 days. The $\mathrm{C}$ and $\mathrm{N}$ bulls used to father the purebred animals were the same ones used to father the crossbred animals.

From birth to early weaning (63 days of age), the calves and cows remained in areas of natural pasture at 0.9 AU ha-1 (AU=animal unit) stocking density. After weaning, all calves were kept in a pen for 5 days, where they received concentrate with $22 \%$ crude protein. For the following 30 days, the diet was based on corn silage and concentrate at $1 \%$ body weight (BW) containing $18 \%$ crude protein. After this period, the calves were transferred to an area of millet pasture (Penisetum americanum Leeke), receiving the same concentrate at the same proportion. From five to 12 months of age,

Pesq. agropec. bras., Brasília, v.55, e01821, 2020

DOI: 10.1590/S1678-3921.pab2020.v55.01821 
the animals remained in areas of natural pasture, with a supplement of corn silage and concentrate (1\% BW).

The calves were weighed at birth, at early weaning, and at 210 and 365 days of age. The increase of weight was calculated from the difference between each weighing divided by the number of days. Morphometric body measurements were taken together with each weighing: foreleg circumference (FC), thoracic girth (TG), body length (BL) and croup height $(\mathrm{CH})$. During the different growth phases, calves up to 12 months of age were evaluated to verify whether the development in measurement and weight remained unchanged between the different genetic groups and mating systems under study. Foreleg circumference, thoracic girth, and body length were measured with a tape, and croup height was measured using a square. The foreleg circumference was measured halfway between the radiocarpal joint and the olecranon. Thoracic girth included the complete thoracic circumference of the animal, passing through the upper withers and lower sternum. Body length was measured between the scapulohumeral and coxofemoral joints, and croup height was taken as the distance between the upper part of the sacrum and the ground.

The effects of genetic group and heterosis on body weight, average daily weight gain, morphometric measurements and their increase, and the relationship between weight and measurements $\left(\mathrm{kg} \mathrm{m}^{-1}\right)$ were evaluated for the different intervals. The heterosis was obtained by dividing the average value of the crossbred animals from each generation (G2 and G3) by the average value of the purebred animals, and the result was subtracted from 1 and multiplied by 100 (Menezes et al., 2005; Pacheco et al., 2010). The retained heterosis was calculated by dividing the average of all crossbred animals by the average of the purebred animals, subtracting the result from 1 and multiplying by 100 (Menezes et al., 2005; Pacheco et al., 2010).

The adopted experimental design was completely randomized, with different number of replicates per genetic group. Data of the different intervals were subjected to the analysis of variance, and the means were compared by t-test, with the aid of the SAS 9.0 statistical software SAS (SAS Institute Inc., Cary, NC, USA), using the following mathematical model: $\mathrm{Y}_{\mathrm{ijklm}}=\mu+\mathrm{P}_{\mathrm{i}}+\mathrm{SA}_{\mathrm{j}}+\mathrm{P} \times \mathrm{SA}_{\mathrm{ij}}+\mathrm{GGk}\left(\mathrm{SA}_{\mathrm{j}}\right)+$ $\mathrm{P} \times \mathrm{GG}(\mathrm{SA})_{\mathrm{ijk}}+\mathrm{AM} 1+\mathrm{OP}_{\mathrm{m}}+\mathrm{E}_{\mathrm{ijklm}}$, where: $Y_{\mathrm{ijk} k \mathrm{~m}}$ are the dependent variables (body measurements); $\mu$ is the average value of all observations of the characteristic; $\mathrm{P}_{\mathrm{i}}$ is the effect of the $\mathrm{i}^{\text {th }}$ age for the measurements equal to 1 (birth), 2 (63 days), 3 (210 days), and 4 (365 days); $\mathrm{SA}_{\mathrm{j}}$ is the effect of the $\mathrm{j}^{\text {th }}$ breeding system equal to 1 (purebred), 2 (crossbreds from G2), and 3 (crossbreds from G3); $\mathrm{P} \times \mathrm{SA}_{\mathrm{ij}}$ is the effect of the interaction between the $\mathrm{i}^{\text {th }}$ interval and $\mathrm{j}^{\text {th }}$ breeding systems; $\operatorname{GGk}\left(\mathrm{SA}_{\mathrm{j}}\right)$ is the effect of the genetic group with index $\mathrm{k}$ equal to 1 (Charolais) and 2 (Nellore), within $\mathrm{SA}_{\mathrm{j}} ; 1$ (3/4C 1/4N) and $2(3 / 4 \mathrm{~N} 1 / 4 \mathrm{C})$ within $\mathrm{SA}_{\mathrm{j}} 2$, and $1(5 / 8 \mathrm{C} 3 / 8 \mathrm{~N})$ and $2(5 / 8 \mathrm{~N} 3 / 8 \mathrm{C})$ within $\mathrm{SA}_{\mathrm{j}} 3 ; \mathrm{P}_{\mathrm{i}} \times \mathrm{GGk}\left(\mathrm{SA}_{\mathrm{j}}\right)$ is the effect of the interaction between the $\mathrm{i}^{\text {th }} \mathrm{P}$ and $\mathrm{k}^{\text {th }}$ genetic group within the $\mathrm{j}^{\text {th }}$ breeding system; AM 1 is the covariate age of the mother, for animals of index $1(\beta \times \mathrm{s}$ are regression coefficients associated with age of mother in years ( $\mathrm{AM}, 3 \leq \mathrm{AM} \leq 12)$; $\mathrm{OP}_{\mathrm{m}}$ is the covariate calves birth order $\mathrm{m}$; and $\mathrm{E}_{\mathrm{ijklm}}$ is the residual effect.

The covariables AM and OP were tested with the quadratic model and, as they were not significant, they were removed from the model.

\section{Results and Discussion}

The Charolais animals were superior to the Nellore ones for total weight gain and total average daily gain, from birth to 365 days of age (Table 1). The superiority within each breeding generation of the purebred Charolais animals, or those with a predominance of Charolais genes over the purebred Nellore animals, or with a predominance of Nellore genes, is due to the different characteristics of the selection process and the respective fitness of each breed. The Charolais animals were selected for their weight gain and greater body weight at maturity, in comparison to Nellore animals, since they are more adapted to meat production and traction strength, both of which require great musculature (Pacheco et al., 2010). The Natural selection of indicus breeds such as Nellore, included a tolerance to high-temperature climates, thus resulting in animals with a thinner, lighter body structure, with less bone and muscle mass, a thinner but larger hide with greater skinfolds, and better fat deposition than the Charolais (Calegare et al., 2009). Menezes et al. (2005) found additive genetic effect for muscle deposition in the carcass of predominant Charolais animals, in comparison to the predominant Nellore and 
these showed a greater potential for the deposition of adipose tissue than the predominant Charolais (24.69 vs $21.61 \%$ ).

Heterosis for weight gain was positive for each interval, except between 210 and 365 days of age in G2. Animals from G2 and G3 showed a significant heterosis for total weight gain and daily weight gain. To corroborate this, from 63 to 210, and from 210 to 365 days of age, the Charolais animals in the present study showed a greater average daily weight gain and a greater absolute daily weight gain than the Nellore animals. The G2 animals with a predominance of Charolais showed a greater average daily weight gain from 210 to 365 days of age than animals with a predominance of Nellore breed, whereas for G3, no significant differences were observed. The results for average daily weight gain showed that $\mathrm{G} 2$ animals may have benefitted from maternal heterozygosis, as their mothers came from the first generation of crossbreeds (F1), showing 100\% heterozygosity (Leal et al., 2018). Due to this heterozygosis, the cows produce more milk with a higher level of total dry extract than those of pure breeds (Rodrigues et al., 2014; Mendonça et al., 2019). The heterosis of G3 animals for weight gain and average daily gain are influenced by individual heterozygosis, which was significant in all age ranges, except for the period from birth to weaning (1-63 days of age). This lack of development in G3 animals of similar weight shows, by their heterozygosity, a greater homogeneity in the animals that comprise the generation, regardless of whether the animal genes are predominantly Charolais or Nellore.

Greater increases of total body length were observed for the Charolais animals in relation to the Nellore ones, while the Nellore animals were superior to Charolais for the total increase of croup height (Table 2). As to structure and conformation, it is expected that the purebred animals, or predominantly Charolais animals have longer carcasses, while the purebred animals or predominantly Nellore animals have longer hind and forelegs (Menezes et al., 2005). The increase of Nellore genes in crossings with European breeds reduces the length of the carcasses and increases the length of the limbs, highlighting the morphological differences and additive genetic effect between Bos indicus and Bos Taurus, as well as the additive genetic effect of the two breeds as being responsible for the variation (Mendonça et al., 2019); these results are reversed when Charolais genes are added (Menezes et al., 2005). The superiority in croup height of the Nellore animals is a

Table 1. Mean values, standard errors, and heterosis, for weight gain and average daily gain in beef cattle under development from 1 to 365 days of age, for genetic group and breeding system ${ }^{(1)}$.

\begin{tabular}{|c|c|c|c|c|c|c|c|c|c|c|c|c|}
\hline \multicolumn{3}{|c|}{ Genetic composition } & \multicolumn{4}{|c|}{ Weight gain $(\mathrm{kg})$ according to age } & \multirow[t]{2}{*}{ SEM } & \multicolumn{4}{|c|}{ Average daily gain $(\mathrm{kg})$ according to age } & \multirow[t]{2}{*}{ SEM } \\
\hline Bull & Cow & Calf & $1-63$ & $63-210$ & $210-365$ & $1-365$ & & $1-63$ & $63-210$ & $210-365$ & $1-365$ & \\
\hline $\mathrm{C}$ & $\mathrm{C}$ & $\mathrm{C}$ & $27.02 \mathrm{a}$ & $66.08 \mathrm{a}$ & $66.23 \mathrm{a}$ & $162.60 \mathrm{a}$ & 4.61 & $0.45 b$ & $0.45 \mathrm{a}$ & $0.46 \mathrm{a}$ & $0.44 \mathrm{a}$ & 0.03 \\
\hline $\mathrm{N}$ & $\mathrm{N}$ & $\mathrm{N}$ & $37.77 \mathrm{a}$ & $55.43 \mathrm{a}$ & $33.99 b$ & $118.66 \mathrm{~b}$ & 5.26 & $0.55 \mathrm{a}$ & $0.37 \mathrm{~b}$ & $0.23 b$ & $0.34 \mathrm{~b}$ & 0.03 \\
\hline \multicolumn{3}{|c|}{ Mean purebred } & $32.39 \mathrm{~A}$ & $60.76 \mathrm{~B}$ & $50.11 \mathrm{~A}$ & 140.63B & 3.49 & $0.50 \mathrm{~B}$ & $0.41 \mathrm{~B}$ & $0.34 \mathrm{~B}$ & $0.39 \mathrm{~B}$ & 0.02 \\
\hline $\mathrm{C}$ & $1 / 2 \mathrm{~N} 1 / 2 \mathrm{C}$ & $3 / 4 \mathrm{C} 1 / 4 \mathrm{~N}$ & $38.68 \mathrm{a}$ & $67.26 \mathrm{a}$ & $63.34 \mathrm{a}$ & $174.58 \mathrm{a}$ & 5.87 & $0.64 \mathrm{a}$ & $0.46 \mathrm{a}$ & $0.44 \mathrm{a}$ & $0.47 \mathrm{a}$ & 0.03 \\
\hline $\mathrm{N}$ & $1 / 2 \mathrm{C} 1 / 2 \mathrm{~N}$ & $3 / 4 \mathrm{~N} 1 / 4 \mathrm{C}$ & $43.31 \mathrm{a}$ & $65.44 \mathrm{a}$ & $31.74 \mathrm{~b}$ & $144.31 \mathrm{~b}$ & 8.28 & $0.71^{\mathrm{a}}$ & $0.45^{\mathrm{a}}$ & $0.22 \mathrm{~b}$ & $0.39 \mathrm{a}$ & 0.05 \\
\hline \multicolumn{3}{|c|}{ Mean G2 } & $40.99 \mathrm{~A}$ & $66.35 \mathrm{AB}$ & $47.54 \mathrm{~A}$ & $159.45 \mathrm{~A}$ & 5.22 & $0.67 \mathrm{~A}$ & $0.45 \mathrm{AB}$ & $0.33 \mathrm{~B}$ & $0.43 \mathrm{AB}$ & 0.03 \\
\hline $\mathrm{C}$ & $3 / 4 \mathrm{~N} 1 / 4 \mathrm{C}$ & $5 / 8 \mathrm{C} 3 / 8 \mathrm{~N}$ & $37.20 \mathrm{a}$ & $75.41 \mathrm{a}$ & $64.08 \mathrm{a}$ & $171.34 \mathrm{a}$ & 3.73 & $0.56 \mathrm{a}$ & $0.51 \mathrm{a}$ & $0.44 \mathrm{a}$ & $0.48 \mathrm{a}$ & 0.02 \\
\hline $\mathrm{N}$ & $3 / 4 \mathrm{C} 1 / 4 \mathrm{~N}$ & $5 / 8 \mathrm{~N} 3 / 8 \mathrm{C}$ & $31.00 \mathrm{a}$ & $73.16 \mathrm{a}$ & $53.54 \mathrm{a}$ & $164.95 \mathrm{a}$ & 4.29 & $0.52 \mathrm{a}$ & $0.50 \mathrm{a}$ & $0.37 \mathrm{a}$ & $0.44 \mathrm{a}$ & 0.02 \\
\hline \multicolumn{3}{|c|}{ Mean G3 } & $34.10 \mathrm{~A}$ & $74.29 \mathrm{~A}$ & $58.81 \mathrm{~A}$ & $168.14 \mathrm{~A}$ & 2.87 & $0.54 \mathrm{~B}$ & $0.51 \mathrm{~A}$ & $0.41 \mathrm{~A}$ & $0.46 \mathrm{~A}$ & 0.02 \\
\hline \multirow{2}{*}{\multicolumn{2}{|c|}{ Heterosis $^{(2)}(\%)$}} & G2 & 26.55 & 9.20 & -5.13 & $13.38^{*}$ & & $34.00 *$ & 9.76 & -2.94 & 10.26 & \\
\hline & & G3 & 5.28 & $22.27 *$ & 17.36 & $19.56^{*}$ & & 8.00 & $24.39^{*}$ & $20.59^{*}$ & $17.95^{*}$ & \\
\hline \multicolumn{3}{|c|}{ Retained heterosis $^{(3)}$} & 15.92 & 15.73 & 6.12 & 16.47 & & 21.00 & 17.07 & 8.82 & 14.10 & \\
\hline \multirow{2}{*}{\multicolumn{2}{|c|}{ Differences crossbred $\mathrm{vs}^{(4)}$}} & $\mathrm{C}(\%)$ & 38.95 & 6.42 & -19.71 & 0.73 & & 34.44 & 6.67 & -19.57 & 1.14 & \\
\hline & & $N(\%)$ & -0.60 & 26.86 & 56.44 & 38.04 & & 10.00 & 29.73 & 60.87 & 30.88 & \\
\hline
\end{tabular}

${ }^{(1)}$ Means with equal, lowercase letters in the same column differ within the breeding system, by the t-test, at $5 \%$ probability. Means with equal, uppercase letters in the same column differ between breeding systems, by the t-test, at $5 \%$ probability. *Statistical difference at $5 \%$ probability in the comparison between crossbred and purebred animals. C, Charolais; N, Nellore; G2, second generation; G3, third generation. (2) [(Mean of the crossbred generation / overall mean of the purebred generations) - 1$] \times 100 .{ }^{(3)}[($ Mean of the crossbred generations / overall mean of the purebred generations $)-1] \times 100 .{ }^{(4)}[($ Overall mean of the crossbred generations / individual mean of the purebred generations) - 1] $\times 100$. 
result of the evolutionary process of natural selection in environments with high temperatures (Randhawa et al., 2014). Under such conditions, a greater distance between the ground and the animal's body results in body temperature being more efficiently maintained on warmer days (Vaz et al., 2016). The croup height has a heritability equal to 0.28 , a value considered moderate (Silveira et al., 2017). In addition, the mothers of calves from the two generations of crossbred animals were also crossbreeds, affording possible benefits from maternal heterosis (Wakchaure et al., 2015; Leal et al., 2018) through an increase of milk production and nutrient density (Mendonça et al., 2019), providing the calves with a greater input of energy, and relating positively to croup height (Rodrigues et al., 2014).

Purebred animals did not differ for the increase in foreleg circumference in any of the time intervals (Table 3). Charolais animals showed a greater total increase of thoracic girth from birth to 365 days. Foreleg circumference and thoracic girth are important, as they are positively related to the muscular development of the animals (Menezes et al., 2005), as well as to the size and conformation of the carcass (Pacheco et al., 2014), and to its cut yield (Choy et al., 2017). Cardoso et al. (2020) developed equations to determine the weight of commercial cuts and the degree of carcass fat, using morphometric measurements and ultrasound, and they found that carcass measurements were responsible for explaining 44 to $94 \%$ of the final cut weight of meat. Charolais animals were superior due to the intensive selection for musculature, weight gain, and adult weight (Vaz et al., 2016).

For the total increase of measurements, a significant heterosis was found in both generations for body length and height in $\mathrm{G} 3$, in relation to $\mathrm{G} 2$, as well as in the purebred animals, for foreleg circumference, and in G3, for thoracic girth compared to the purebred animals (Tables 2 and 3).

No differences were found between the genetic groups within the breeding systems for increases of weight in relation to increases in foreleg circumference, thoracic girth, or body length, for the different stages under evaluation (Tables 4 and 5).

The Charolais animals gained more weight per unit of measurement for croup height from 63 to 365 days of age than the Nellore animals. Comparing the generations, a difference was only observed in those variables that relate weight gain to increases in foreleg circumference and thoracic girth from 210 to 365 days of age, for which the G3 animals superior to the

Table 2. Mean values, standard errors, and heterosis, for gains of body length and croup height in beef cattle under development from 1 to 365 days of age, for genetic group and breeding system ${ }^{(1)}$.

\begin{tabular}{|c|c|c|c|c|c|c|c|c|c|c|c|c|}
\hline \multicolumn{3}{|c|}{ Genetic composition } & \multicolumn{4}{|c|}{ Body length $(\mathrm{cm})$ according to age } & \multirow[t]{2}{*}{ SEM } & \multicolumn{4}{|c|}{ Croup height $(\mathrm{cm})$ according to age } & \multirow[t]{2}{*}{ SEM } \\
\hline Bull & Cow & Calf & $1-63$ & $63-210$ & $210-365$ & $1-365$ & & $1-63$ & $63-210$ & $210-365$ & $1-365$ & \\
\hline $\mathrm{C}$ & $\mathrm{C}$ & $\mathrm{C}$ & $15.90 \mathrm{a}$ & $20.04 \mathrm{a}$ & $13.25 \mathrm{a}$ & $49.52 \mathrm{a}$ & 1.25 & $8.68 b$ & $12.58 \mathrm{a}$ & $10.13 \mathrm{a}$ & $31.82 \mathrm{~b}$ & 0.84 \\
\hline $\mathrm{N}$ & $\mathrm{N}$ & $\mathrm{N}$ & $18.66 \mathrm{a}$ & $18.94 \mathrm{a}$ & $8.80 \mathrm{~b}$ & $45.07 \mathrm{~b}$ & 1.42 & $12.40 \mathrm{a}$ & $13.45 \mathrm{a}$ & $10.36 \mathrm{a}$ & $35.22 \mathrm{a}$ & 0.96 \\
\hline \multicolumn{3}{|c|}{ Mean purebred } & $17.28 \mathrm{~A}$ & $19.49 \mathrm{~A}$ & $11.02 \mathrm{~A}$ & $47.30 \mathrm{~B}$ & 0.94 & $10.54 \mathrm{~A}$ & $13.01 \mathrm{~A}$ & $10.24 \mathrm{~B}$ & $33.52 \mathrm{~B}$ & 0.63 \\
\hline $\mathrm{C}$ & $1 / 2 \mathrm{~N} 1 / 2 \mathrm{C}$ & $3 / 4 \mathrm{C} 1 / 4 \mathrm{~N}$ & $19.69 \mathrm{a}$ & $18.59 \mathrm{a}$ & $11.92 \mathrm{a}$ & $52.16 \mathrm{a}$ & 1.56 & $12.47 \mathrm{a}$ & $13.80 \mathrm{a}$ & $10.52 \mathrm{a}$ & $37.37 \mathrm{a}$ & 1.05 \\
\hline $\mathrm{N}$ & $1 / 2 \mathrm{C} 1 / 2 \mathrm{~N}$ & $3 / 4 \mathrm{~N} 1 / 4 \mathrm{C}$ & $20.87 \mathrm{a}$ & $18.65 \mathrm{a}$ & $8.98 \mathrm{a}$ & $49.42 \mathrm{a}$ & 2.24 & $12.37 \mathrm{a}$ & $15.48 \mathrm{a}$ & $7.48 \mathrm{a}$ & $35.70 \mathrm{a}$ & 1.50 \\
\hline \multicolumn{3}{|c|}{ Mean G2 } & $20.28 \mathrm{~A}$ & $18.62 \mathrm{~A}$ & $10.45 \mathrm{~A}$ & $50.79 \mathrm{~A}$ & 1.40 & $12.42 \mathrm{~A}$ & $14.64 \mathrm{~A}$ & $9.00 \mathrm{~B}$ & $36.54 \mathrm{~A}$ & 0.94 \\
\hline $\mathrm{C}$ & $3 / 4 \mathrm{~N} 1 / 4 \mathrm{C}$ & $5 / 8 \mathrm{C} 3 / 8 \mathrm{~N}$ & $18.05 \mathrm{a}$ & $22.11 \mathrm{a}$ & $12.91 \mathrm{a}$ & $51.98 \mathrm{a}$ & 1.01 & $11.90 \mathrm{a}$ & $14.58 \mathrm{a}$ & $12.08 \mathrm{a}$ & $37.94 \mathrm{a}$ & 0.68 \\
\hline $\mathrm{N}$ & $3 / 4 \mathrm{C} 1 / 4 \mathrm{~N}$ & $5 / 8 \mathrm{~N} 3 / 8 \mathrm{C}$ & $17.29 \mathrm{a}$ & $19.62 \mathrm{a}$ & $12.29 \mathrm{a}$ & $49.73 \mathrm{a}$ & 1.16 & $10.85 \mathrm{a}$ & $13.79 \mathrm{a}$ & $12.61 \mathrm{a}$ & $37.85 \mathrm{a}$ & 0.78 \\
\hline \multicolumn{3}{|c|}{ Mean G3 } & $17.67 \mathrm{~A}$ & $20.87 \mathrm{~A}$ & $12.60 \mathrm{~A}$ & $50.86 \mathrm{~A}$ & 0.77 & $11.37 \mathrm{~A}$ & $14.18 \mathrm{~A}$ & $12.34 \mathrm{~A}$ & $37.89 \mathrm{~A}$ & 0.52 \\
\hline \multirow{2}{*}{\multicolumn{2}{|c|}{ Heterosis $^{(2)}(\%)$}} & G2 & 17.36 & -4.46 & 5.17 & $7.38^{*}$ & & 17.84 & 12.53 & -12.11 & $9.01^{*}$ & \\
\hline & & G3 & 2.26 & 7.08 & 14.34 & $7.53^{*}$ & & 7.87 & 8.99 & $20.51 *$ & $13.04 *$ & \\
\hline \multicolumn{3}{|c|}{ Retained heterosis ${ }^{(3)}$} & 9.81 & 1.31 & 4.58 & 7.45 & & 12.86 & 10.76 & 4.20 & 11.02 & \\
\hline \multirow{2}{*}{\multicolumn{2}{|c|}{ Differences crossbred $v^{(4)}$}} & C (\%) & 19.34 & -1.47 & -13.02 & 2.64 & & 37.04 & 14.55 & 5.33 & 16.95 & \\
\hline & & N (\%) & 1.69 & 4.25 & 30.97 & 12.77 & & -4.07 & 7.14 & 2.99 & 5.66 & \\
\hline
\end{tabular}

${ }^{(1)}$ Means with equal, lowercase letters in the same column differ within the breeding system, by the t-test, at $5 \%$ probability. Means with equal, uppercase letters in the same column differ between breeding systems, by the t-test, at $5 \%$ probability.*Statistical difference at $5 \%$ probability comparing crossbred vs purebred animals. C, Charolais; N, Nellore; G2, second generation; G3, third generation. ${ }^{(2)}[($ Mean of the crossbred generations / overall mean of the purebred generations) -1$] \times 100 .{ }^{(3)}[$ (Mean of the crossbred generations / overall mean of the purebred generations) -1$] \times 100 .{ }^{(4)}[($ Overall mean of the crossbred generations / individual mean of the purebred generations) - 1] $\times 100$. 
Table 3. Mean values, standard errors, and heterosis for gains of foreleg circumference and thoracic girth in beef cattle under development from 1 to 365 days of age, for genetic group and breeding system ${ }^{(1)}$.

\begin{tabular}{|c|c|c|c|c|c|c|c|c|c|c|c|c|}
\hline \multicolumn{3}{|c|}{ Genetic composition } & \multicolumn{4}{|c|}{ Foreleg circumference $(\mathrm{cm})$ according to age } & \multirow[t]{2}{*}{ SEM } & \multicolumn{4}{|c|}{ Thoracic girth $(\mathrm{cm})$ according to age } & \multirow[t]{2}{*}{ SEM } \\
\hline Bull & Cow & Calf & $1-63$ & $63-210$ & $210-365$ & $1-365$ & & $1-63$ & $63-210$ & $210-365$ & $1-365$ & \\
\hline $\mathrm{C}$ & $\mathrm{C}$ & $\mathrm{C}$ & $3.43 \mathrm{a}$ & $4.95 \mathrm{a}$ & $2.14 \mathrm{a}$ & $10.59 \mathrm{a}$ & 0.43 & $18.60 \mathrm{~b}$ & $23.46 \mathrm{a}$ & $22.43 \mathrm{a}$ & $65.08 \mathrm{a}$ & 1.36 \\
\hline $\mathrm{N}$ & $\mathrm{N}$ & $\mathrm{N}$ & $4.67 \mathrm{a}$ & $4.27 \mathrm{a}$ & $1.52 \mathrm{a}$ & $9.70 \mathrm{a}$ & 0.49 & $23.20 \mathrm{a}$ & $21.56 \mathrm{a}$ & $16.11 b$ & $58.38 \mathrm{~b}$ & 1.55 \\
\hline \multicolumn{3}{|c|}{ Mean purebred } & $4.05 \mathrm{~A}$ & $4.61 \mathrm{~A}$ & $1.83 \mathrm{~B}$ & 10.14B & 0.32 & $20.90 \mathrm{~A}$ & $22.51 \mathrm{~B}$ & 19.27AB & $61.73 \mathrm{~B}$ & 1.03 \\
\hline $\mathrm{C}$ & $1 / 2 \mathrm{~N} 1 / 2 \mathrm{C}$ & $3 / 4 \mathrm{C} 1 / 4 \mathrm{~N}$ & $3.38 \mathrm{a}$ & $4.81 \mathrm{a}$ & $3.08 \mathrm{a}$ & $11.88 \mathrm{a}$ & 0.53 & $21.83 \mathrm{a}$ & $22.12 \mathrm{a}$ & $20.83 a$ & $66.83 a$ & 1.71 \\
\hline $\mathrm{N}$ & $1 / 2 \mathrm{C} 1 / 2 \mathrm{~N}$ & $3 / 4 \mathrm{~N} 1 / 4 \mathrm{C}$ & $3.94 \mathrm{a}$ & $4.50 \mathrm{a}$ & $0.61 \mathrm{~b}$ & $9.39 \mathrm{~b}$ & 0.76 & $23.72 \mathrm{a}$ & $21.39 \mathrm{a}$ & $12.72 b$ & $59.06 \mathrm{~b}$ & 2.43 \\
\hline \multicolumn{3}{|c|}{ Mean G2 } & $3.66 \mathrm{~A}$ & $4.66 \mathrm{~A}$ & $1.84 \mathrm{AB}$ & $10.64 \mathrm{~B}$ & 0.47 & $22.78 \mathrm{~A}$ & $21.75 \mathrm{~B}$ & $16.78 \mathrm{~B}$ & $62.94 \mathrm{AB}$ & 1.53 \\
\hline $\mathrm{C}$ & $3 / 4 \mathrm{~N} 1 / 4 \mathrm{C}$ & $5 / 8 \mathrm{C} 3 / 8 \mathrm{~N}$ & $4.69 \mathrm{a}$ & $4.92 \mathrm{a}$ & $2.53 \mathrm{a}$ & $11.76 \mathrm{a}$ & 0.34 & $21.60 \mathrm{a}$ & $25.31 \mathrm{a}$ & $21.81 \mathrm{a}$ & $67.24 \mathrm{a}$ & 1.10 \\
\hline $\mathrm{N}$ & $3 / 4 \mathrm{C} 1 / 4 \mathrm{~N}$ & $5 / 8 \mathrm{~N} 3 / 8 \mathrm{C}$ & $3.14 \mathrm{~b}$ & $5.55 \mathrm{a}$ & $2.80 \mathrm{a}$ & $11.95 \mathrm{a}$ & 0.39 & $19.41 \mathrm{a}$ & $25.44 \mathrm{a}$ & $19.32 \mathrm{a}$ & $65.59 \mathrm{a}$ & 1.26 \\
\hline \multicolumn{3}{|c|}{ Mean G3 } & $3.91 \mathrm{~A}$ & $5.23 \mathrm{~A}$ & $2.67 \mathrm{~A}$ & $11.85 \mathrm{~A}$ & 0.26 & $20.50 \mathrm{~A}$ & $25.37 \mathrm{~A}$ & $20.56 \mathrm{~A}$ & $66.41 \mathrm{~A}$ & 0.84 \\
\hline \multirow{2}{*}{\multicolumn{2}{|c|}{ Heterosis $^{(2)}(\%)$}} & G2 & -9.63 & 1.08 & 0.55 & 4.93 & & 9.00 & -3.38 & -12.92 & 1.96 & \\
\hline & & G3 & -3.46 & 13.45 & $45.90 *$ & $16.86^{*}$ & & -1.91 & $12.71^{*}$ & 6.69 & $7.58^{*}$ & \\
\hline \multicolumn{3}{|c|}{ Retained heterosis ${ }^{(3)}$} & -6.54 & 7.27 & 23.22 & 10.90 & & 3.54 & 4.66 & -3.11 & 4.77 & \\
\hline \multirow{2}{*}{\multicolumn{2}{|c|}{ Differences crossbred $\mathbf{v s}^{(4)}$}} & $\mathrm{C}(\%)$ & 10.35 & -0.10 & 5.37 & 6.19 & & 16.34 & 0.43 & -16.76 & -0.62 & \\
\hline & & $\mathrm{N}(\%)$ & -18.95 & 15.81 & 48.36 & 15.93 & & -6.72 & 9.28 & 15.89 & 10.78 & \\
\hline
\end{tabular}

${ }^{(1)}$ Means with equal, lowercase letters in the same column differ within the breeding system, by the t-test, at $5 \%$ probability. Means with equal, uppercase letters in the same column differ between breeding systems, by the t-test, at $5 \%$ probability. ${ }^{*}$ Statistical difference at $5 \%$ probability comparing crossbred vs purebred animals. C, Charolais; N, Nellore; G2, second generation; G3, third generation. ${ }^{(2)}[($ Mean of the crossbred generations / overall mean of the purebred generations) - 1] $\times 100 .{ }^{(3)}\left[(\right.$ Mean of the crossbred generations / overall mean of the purebred generations) - 1$] \times 100 .{ }^{(4)}[($ Overall mean of the crossbred generations / individual mean of the purebred generations) - 1] $\times 100$.

Table 4. Mean values, standard errors, and heterosis for gain of body weight (GBW) / gain of foreleg circumference (GFC), and GBW / gain of thoracic girth (GTG) in beef cattle under development from 1 to 365 days of age, for genetic group and breeding system ${ }^{(1)}$.

\begin{tabular}{|c|c|c|c|c|c|c|c|c|c|c|c|c|c|}
\hline \multicolumn{4}{|c|}{ Genetic composition } & \multicolumn{4}{|c|}{ GBW / GFC $\left(\mathrm{kg} \mathrm{cm}^{-1}\right)$ according to age } & \multirow[t]{2}{*}{ SEM } & \multicolumn{4}{|c|}{ GBW / GTG $\left(\mathrm{kg} \mathrm{cm}^{-1}\right)$ according to age } & \multirow[t]{2}{*}{ SEM } \\
\hline Bull & Cow & & Calf & $1-63$ & $63-210$ & $210-365$ & $1-365$ & & $1-63$ & $63-210$ & $210-365$ & $1-365$ & \\
\hline $\mathrm{C}$ & $\mathrm{C}$ & & $\mathrm{C}$ & $10.17 \mathrm{a}$ & $15.44 \mathrm{a}$ & $14.11 \mathrm{a}$ & $16.16 \mathrm{a}$ & 2.52 & $1.55 \mathrm{a}$ & $2.83 \mathrm{a}$ & $1.93 \mathrm{a}$ & $2.46 \mathrm{a}$ & 0.24 \\
\hline $\mathrm{N}$ & $\mathrm{N}$ & & $\mathrm{N}$ & $8.39 \mathrm{a}$ & $14.57 \mathrm{a}$ & $11.68 \mathrm{a}$ & $12.39 \mathrm{a}$ & 2.88 & $1.56 \mathrm{a}$ & $2.57 \mathrm{a}$ & $2.14 \mathrm{a}$ & $2.06 \mathrm{a}$ & 0.27 \\
\hline \multicolumn{4}{|c|}{ Mean purebred } & $9.28 \mathrm{~A}$ & $15.01 \mathrm{~A}$ & $12.89 \mathrm{~B}$ & $14.28 \mathrm{~A}$ & 1.91 & $1.56 \mathrm{~A}$ & $2.69 \mathrm{~A}$ & $2.04 \mathrm{~B}$ & $2.26 \mathrm{~A}$ & 0.18 \\
\hline $\mathrm{C}$ & $1 / 2 \mathrm{~N} 1 / 2 \mathrm{C}$ & $3 / 4 \mathrm{C}$ & C $1 / 4 \mathrm{~N}$ & $13.73 \mathrm{a}$ & $15.59 \mathrm{a}$ & $16.25 \mathrm{a}$ & $13.81 \mathrm{a}$ & 3.13 & $1.80 \mathrm{a}$ & $3.01 \mathrm{a}$ & $2.99 \mathrm{a}$ & $2.54 \mathrm{a}$ & 0.29 \\
\hline $\mathrm{N}$ & $1 / 2 \mathrm{C} 1 / 2 \mathrm{~N}$ & $3 / 4 \mathrm{~N}$ & $\mathrm{~N} 1 / 4 \mathrm{C}$ & $11.83 \mathrm{a}$ & $18.42 \mathrm{a}$ & $14.15 \mathrm{a}$ & $15.57 \mathrm{a}$ & 4.53 & $1.81 \mathrm{a}$ & $3.11 \mathrm{a}$ & $2.64 \mathrm{a}$ & $2.39 \mathrm{a}$ & 0.42 \\
\hline \multicolumn{4}{|c|}{ Mean G2 } & $12.78 \mathrm{~A}$ & $17.00 \mathrm{~A}$ & $15.20 \mathrm{AB}$ & $14.69 \mathrm{~A}$ & 2.81 & $1.80 \mathrm{~A}$ & $3.06 \mathrm{~A}$ & $2.81 \mathrm{~A}$ & $2.46 \mathrm{~A}$ & 0.26 \\
\hline $\mathrm{C}$ & $3 / 4 \mathrm{~N} 1 / 4 \mathrm{C}$ & $5 / 8 \mathrm{C}$ & C $3 / 8 \mathrm{~N}$ & $9.63 \mathrm{a}$ & $19.60 \mathrm{a}$ & $18.51 \mathrm{a}$ & $15.05 \mathrm{a}$ & 2.05 & $1.74 \mathrm{a}$ & $2.97 \mathrm{a}$ & $2.95 \mathrm{a}$ & $2.54 \mathrm{a}$ & 0.19 \\
\hline $\mathrm{N}$ & $3 / 4 \mathrm{C} 1 / 4 \mathrm{~N}$ & $5 / 8 \mathrm{~N}$ & N $3 / 8 \mathrm{C}$ & $12.28 \mathrm{a}$ & $14.21 \mathrm{a}$ & $20.09 \mathrm{a}$ & $13.89 \mathrm{a}$ & 2.37 & $1.57 \mathrm{a}$ & $2.88 \mathrm{a}$ & $2.92 \mathrm{a}$ & $2.48 \mathrm{a}$ & 0.22 \\
\hline \multicolumn{4}{|c|}{ Mean G3 } & $10.96 \mathrm{~A}$ & $16.90 \mathrm{~A}$ & $19.30 \mathrm{~A}$ & $14.47 \mathrm{~A}$ & 1.56 & $1.66 \mathrm{~A}$ & $2.93 \mathrm{~A}$ & $2.94 \mathrm{~A}$ & $2.51 \mathrm{~A}$ & 0.15 \\
\hline \multirow{2}{*}{\multicolumn{2}{|c|}{ Heterosis $^{(2)}(\%)$}} & & $\mathrm{G} 2$ & 37.72 & 13.26 & 17.92 & 2.87 & & 15.38 & 13.75 & $37.75^{*}$ & 8.85 & \\
\hline & & & G3 & 18.10 & 12.59 & $49.73^{*}$ & 1.33 & & 6.41 & 8.92 & $44.12 *$ & 11.06 & \\
\hline \multicolumn{4}{|c|}{ Retained heterosis ${ }^{(3)}$} & 27.91 & 12.92 & 33.82 & 2.10 & & 10.90 & 11.34 & 40.93 & 9.96 & \\
\hline \multirow{2}{*}{\multicolumn{3}{|c|}{ Differences crossbred $v^{(4)}$}} & $\mathrm{C}(\%)$ & 16.72 & 9.78 & 22.25 & -9.78 & & 11.61 & 5.83 & 48.96 & 1.02 & \\
\hline & & & $\mathrm{N}(\%)$ & 41.48 & 16.33 & 47.69 & 17.68 & & 10.90 & 16.54 & 34.35 & 20.63 & \\
\hline
\end{tabular}

${ }^{(1)}$ Means with equal, lowercase letters in the same column differ within the breeding system, by the t-test, at 5\% probability. Means with equal, uppercase letters in the same column differ between breeding systems, by the t-test, at $5 \%$ probability. ${ }^{*}$ Statistical difference at $5 \%$ probability comparing crossbred vs purebred animals. C, Charolais; N, Nellore; G2, second generation; G3, third generation. ${ }^{(2)}$ [(Mean of the crossbred generations / overall mean of the purebred generations) - 1] $\times 100 .{ }^{(3)}\left[(\right.$ Mean of the crossbred generations / overall mean of the purebred generations) -1$] \times 100 .{ }^{(4)}[($ Overall mean of the crossbred generations / individual mean of the purebred generations) - 1] $\times 100$.

Pesq. agropec. bras., Brasília, v.55, e01821, 2020

DOI: 10.1590/S1678-3921.pab2020.v55.01821 
purebred ones, and were not different from the G2 animals. The crossbred animals showed superiority for absolute weight gain, average daily gain, body length, croup height, foreleg circumference and thoracic girth, and for the relationship between the increase of weight and the increase of morphometric body measurements. The higher performance of the crossbred animals is probably the result of maternal heterozygosis up to weaning, and direct heterozygosis after that (Leal et al., 2018). In addition, the increases of the crossbred animals were positive in relation to the average value of these characteristics in the purebred animals (Mendonça et al., 2019). The purebred or predominantly Charolais animals showed not only a greater weight gain than the purebred or predominantly Nellore animals, but they showed also a greater body length that directly affected the relationship between weight gain and gain of body length, balancing the greater weight gain of the Charolais animals by their greater body length. Heterosis in these relationships was not significant. The differences for the average increases of the crossbred animals were positive in the comparison to those of the purebred Nellore animals; however, they were negative, when compared to those of the purebred Charolais animals. For the relationship between weight gain and croup height, the superiority of the purebred or predominantly Charolais G2 animals, in comparison to the purebred or predominantly Nellore G2 animals, is attributed to the fact that Charolais animals showed greater weight gains and smaller croup height gains than Nellore animals, for the different time intervals.

In the comparison of the breeding systems, no differences were observed between the average values of the purebred, G2, or G3 animals. This lack of difference is due to the heterosis in this relationship, which is evident, but not significant; it is also due to the positive differences for the average increase of the crossbred animals, in comparison to the purebred Nellore animals, and to the negative differences for this parameter, when comparing the crossbred animals to the purebred Charolais animals.

The complementarity of the breeds is found when the differences of the crossbred animals from both generations are evaluated separately, in relation to the purebred animals. In the present work, for

Table 5. Mean values, standard errors, and heterosis for gain of body weight (GBW) / gain of body length (GBL), and gain of body weight (GBW) / gain of croup height $(\mathrm{GCH})$ in beef cattle under development from 1 to 365 days of age, for genetic group and breeding system ${ }^{(1)}$.

\begin{tabular}{|c|c|c|c|c|c|c|c|c|c|c|c|c|}
\hline \multicolumn{3}{|c|}{ Genetic composition } & \multicolumn{4}{|c|}{ GBW / GBL $\left(\mathrm{kg} \mathrm{cm}^{-1}\right)$ according to age } & \multirow[t]{2}{*}{ SEM } & \multicolumn{4}{|c|}{ GBW / GCH $\left(\mathrm{kg} \mathrm{cm}^{-1}\right)$ according to age } & \multirow[t]{2}{*}{ SEM } \\
\hline Bull & Cow & Calf & $1-63$ & $63-210$ & $210-365$ & $1-365$ & & $1-63$ & $63-210$ & $210-365$ & $1-365$ & \\
\hline $\mathrm{C}$ & $\mathrm{C}$ & $\mathrm{C}$ & $2.66 \mathrm{a}$ & $3.91 \mathrm{a}$ & $5.29 \mathrm{a}$ & $3.16 \mathrm{a}$ & 0.67 & $3.44 \mathrm{a}$ & $5.54 \mathrm{a}$ & $6.85 \mathrm{a}$ & $5.16 \mathrm{a}$ & 0.46 \\
\hline $\mathrm{N}$ & $\mathrm{N}$ & $\mathrm{N}$ & $1.35 \mathrm{a}$ & $2.96 \mathrm{a}$ & $4.07 \mathrm{a}$ & $2.50 \mathrm{a}$ & 0.77 & $2.99 \mathrm{a}$ & $4.17 \mathrm{~b}$ & $3.58 \mathrm{~b}$ & $3.39 \mathrm{~b}$ & 0.51 \\
\hline \multicolumn{3}{|c|}{ Mean purebred generation } & $2.01 \mathrm{~A}$ & $3.44 \mathrm{~A}$ & $4.68 \mathrm{~A}$ & $2.83 \mathrm{~A}$ & 0.51 & $3.22 \mathrm{~A}$ & $4.86 \mathrm{~A}$ & $4.22 \mathrm{~A}$ & $4.28 \mathrm{~A}$ & 0.34 \\
\hline $\mathrm{C}$ & $1 / 2 \mathrm{~N} 1 / 2 \mathrm{C}$ & $3 / 4 \mathrm{C} 1 / 4 \mathrm{~N}$ & $2.59 \mathrm{a}$ & $2.28 \mathrm{a}$ & $5.77 \mathrm{a}$ & $3.55 \mathrm{a}$ & 0.83 & $3.20 \mathrm{a}$ & $4.87 \mathrm{a}$ & $6.27 \mathrm{a}$ & $4.51 \mathrm{a}$ & 0.56 \\
\hline $\mathrm{N}$ & $1 / 2 \mathrm{C} 1 / 2 \mathrm{~N}$ & $3 / 4 \mathrm{~N} 1 / 4 \mathrm{C}$ & $2.21 \mathrm{a}$ & $3.58 \mathrm{a}$ & $4.63 \mathrm{a}$ & $3.01 \mathrm{a}$ & 1.21 & $3.54 \mathrm{a}$ & $4.12 \mathrm{a}$ & $3.64 \mathrm{~b}$ & $3.93 \mathrm{a}$ & 0.80 \\
\hline \multicolumn{3}{|c|}{ Mean of G2 } & $2.40 \mathrm{~A}$ & $2.93 \mathrm{~A}$ & $5.20 \mathrm{~A}$ & $3.28 \mathrm{~A}$ & 0.75 & $3.37 \mathrm{~A}$ & $4.49 \mathrm{~A}$ & $4.95 \mathrm{~A}$ & $4.22 \mathrm{~A}$ & 0.50 \\
\hline $\mathrm{C}$ & $3 / 4 \mathrm{~N} 1 / 4 \mathrm{C}$ & $5 / 8 \mathrm{C} 3 / 8 \mathrm{~N}$ & $2.06 \mathrm{a}$ & $3.42 \mathrm{a}$ & $4.35 \mathrm{a}$ & $3.23 \mathrm{a}$ & 0.55 & $3.20 \mathrm{a}$ & $5.29 \mathrm{a}$ & $5.62 \mathrm{a}$ & $4.50 \mathrm{a}$ & 0.36 \\
\hline $\mathrm{N}$ & $3 / 4 \mathrm{C} 1 / 4 \mathrm{~N}$ & $5 / 8 \mathrm{~N} 3 / 8 \mathrm{C}$ & $1.64 \mathrm{a}$ & $4.12 \mathrm{a}$ & $5.30 \mathrm{a}$ & $3.38 \mathrm{a}$ & 0.63 & $4.07 \mathrm{a}$ & $5.73 \mathrm{a}$ & $4.92 \mathrm{a}$ & $4.43 \mathrm{a}$ & 0.42 \\
\hline \multicolumn{3}{|c|}{ Mean of G3 } & $1.85 \mathrm{~A}$ & $3.77 \mathrm{~A}$ & $4.82 \mathrm{~A}$ & $3.30 \mathrm{~A}$ & 0.43 & $3.63 \mathrm{~A}$ & $5.51 \mathrm{~A}$ & $5.27 \mathrm{~A}$ & $4.47 \mathrm{~A}$ & 0.28 \\
\hline \multirow{2}{*}{\multicolumn{2}{|c|}{ Heterosis $^{(2)}(\%)$}} & $\mathrm{G} 2$ & 19.46 & -14.83 & 11.11 & 15.90 & & 4.66 & -7.61 & 17.30 & -1.40 & \\
\hline & & G3 & -7.96 & 9.59 & 2.99 & 16.61 & & 12.73 & 13.37 & 24.88 & 4.44 & \\
\hline \multicolumn{3}{|c|}{ Retained heterosis ${ }^{(3)}$} & 5.72 & -2.62 & 7.05 & 16.25 & & 8.70 & 2.88 & 21.09 & 1.52 & \\
\hline \multirow{2}{*}{\multicolumn{2}{|c|}{ Differences crossbred vs ${ }^{(4)}$}} & C (\%) & -20.11 & -14.32 & -5.29 & 4.11 & & 1.74 & -9.75 & -25.40 & -15.79 & \\
\hline & & N (\%) & 57.41 & 13.18 & 23.10 & 31.60 & & 17.06 & 19.90 & 42.74 & 28.17 & \\
\hline
\end{tabular}

${ }^{(1)}$ Means with equal, lowercase letters in the same column differ within the breeding system, by the t-test, at $5 \%$ probability. Means with equal, uppercase letters in the same column differ between breeding systems, by the t-test, at $5 \%$ probability.*Statistical difference at $5 \%$ probability comparing crossbred vs purebred animals. C, Charolais; N, Nellore; G2, second generation; G3, third generation. ${ }^{(2)}[($ Mean of the crossbred generations / overall mean of the purebred generations) -1$] \times 100 .{ }^{(3)}[($ Mean of the crossbred generations / overall mean of the purebred generations $)-1] \times 100 .{ }^{(4)}[($ Overall mean of the crossbred generations / individual mean of the purebred generations) - 1] $\times 100$. 
all characteristics analyzed, the complementarity was evidenced in almost all evaluations of weight and measurements, as well as in the relationship between both, when the increase of weight per unit of measurement was analyzed, and the differences resulted positive for the predominance of Bos Taurus, or Bos indicus, according to the selection process (Calegare et al., 2009; Pacheco et al., 2010).

The results showed characteristics of complementarity for the crosses between breeds. Due to the additive genetic merit of the Charolais and Nellore breeds, absolute weight gain, average daily gain, body length, croup height, foreleg circumference, and especially thoracic girth, were all optimized. The same fact was observed in the absolute relationships between weight gain and gains for thoracic girth, body length, and particularly croup height and foreleg circumference. The inclusion of Nellore genes afforded increased gains of croup height, a product of crossbreeding, in comparison to the Charolais breed. The addition of Charolais genes resulted in an increase of weight gain, in the morphometric measurements linked to the muscularity of the animals, as well as in the relationship between weight gain and the gains of morphometric measurements, in comparison to the Nellore breed, which is mainly due to the increase of weight gain.

The effect of complementarity between these two breeds is mainly due to their significant genetic distance (Schiermiester et al., 2015; Mendonça et al., 2019). The characteristics of croup height and withers height are more susceptible to additive genetic gain, since they have moderate heritability value (Silveira et al., 2017). However, for the characteristics of muscularity, such as foreleg circumference and thoracic girth, the expression of complementarity is less pronounced, due to its average heritability (Silveira et al., 2017), furthermore, these characteristics together with weight are highly susceptible to environmental effects such as variations of climate and nutrition (Walmsley et al., 2016). The increase of weight gain is highly correlated with increased gains of morphometric body measurements. Certain body measurements are limited by the physiological maturity of the animal (Sakamoto et al., 2014), in which measurements such as body length and croup height are directly related to, and limited by, the development of bone tissue, while thoracic girth, foreleg circumference, and body weight are mainly related to the development of muscle and adipose tissue, and follow their variation curves (Lee \& Kim, 2010). As such, high, positively correlated responses between thoracic girth and body weight are to be expected (Rezende et al., 2014).

\section{Conclusions}

1. Purebred or second-generation predominantly Charolais crossbred animals are more efficient for gaining weight and have greater muscularity than purebred or predominantly Nellore animals.

2. Nellore animals gain more croup height, but their genetic inclusion does not affect this characteristic in crossed genotypes.

3. The third generation from alternating crossbreeding between Charolais and Nellore produces animals which are homogeneous for both weight gain and morphometric measurements.

4. Crossbred animals are superior to purebred ones in increasing body weight and morphometric measurements, especially third-generation animals, except for the relationship between gain of body weight and gain of croup height.

5. There is no difference for the relationship between weight gain and the gains of morphometric measurements for genotype within the generations of alternating crosses, which shows a strong and homogeneous relationship between increased body weight and skeletal, muscular and adipose development in the animals; this fact suggests that these measurements can be taken and used as good indicators of weight gain and body development of the animal.

\section{Acknowledgments}

To Coordenação de Aperfeiçoamento de Pessoal de Nível Superior (Capes), for financial support (Finance Code 001); and to Conselho Nacional de Desenvolvimento Científico e Tecnológico (CNPq), for grant (303246/2015-4).

\section{References}

CALEGARE, L.; ALENCAR, M.M.; PACKER, I.U.; FERRELL, C.L.; LANNA, D.P.D. Cow/calf preweaning efficiency of Nellore and Bos taurus $\times$ Bos indicus crosses. Journal of Animal Science, v.87, p.740-747, 2009. DOI: https://doi.org/10.2527/jas.2007-0759. 
CARDOSO, L.L.; TAROUCO, J.U.; MACNEIL, M.D.; LOBATO, J.F.P.; DAMBRÓS, M.C.; FREITAS, A.K de.; DEVINCENZI, T.; FEIJÓ, F.D.; CARDOSO, F.F. Sample size and prediction of weight and yield of individual cuts from Braford steers pistol hindquarters. Scientia Agricola, v.77, e20180224, 2020. DOI: https://doi.org/10.1590/1678-992x-2018-0224.

CHOY, Y.H.; LEE, J.G.; MAHBOOB, A.; CHOI, T.J.; RHO, S.H. Genetic correlation between live body measurements and beef cutability traits in Hanwoo steers. Asian-Australian Journal Animal Science, v.30, p.1074-1080, 2017. DOI: https://doi.org/10.5713/ ajas.16.0692.

FAVERO, R.; MENEZES, G.R.O.; TORRES JR., R.A.A.; SILVA, L.O.C.; BONIN, M.N.; FEIJÓ, G.L.D.; ALTRAK, G.; NIWA, M.V.G.; KAZAMA, R.; MIZUBUTI, I.Y.; GOMES, R.C. Crossbreeding applied to systems of beef cattle production to improve performance traits and carcass quality. Animal, v.13, p.2679-2686, 2019. DOI: https://doi.org/10.1017/ S1751731119000855.

FERNANDES, H.J.; TEDESCHI, L.O.; PAULINO, M.F.; PAIVA, L.M. Determination of carcass and body fat compositions of grazing crossbred bulls using body measurements. Journal of Animal Science, v.88, p.1442-1453, 2010. DOI: https://doi.org/10.2527/jas.2009-1919.

GUNAWAN, A.; JAKARIA, J. Application of linear body measurements for predicting weaning and yearling weight of Bali cattle. Animal Production, v.12, p.163-168, 2010. Available at: $\quad<$ https://media.neliti.com/media/publications/63936-ENapplication-of-linear-body-measurements.pdf $>$. Accessed on: Aug. 52020.

HUERTA-LEIDENZ， N.; ATENCIO-VALLADARES， O.; RODRIGUEZ, J.; JEREZ-TIMAURE, N.; VARGAS, G.; RODASGONZÁLEZ, A. Predictability of lean product, bone, and fat trim in beef carcasses from Costa Rica. Meat Science, v.143, p.223229, 2018. DOI: https://doi.org/10.1016/j.meatsci.2018.05.012.

LEAL, W.S.; MACNEIL, M.D.; CARVALHO, H.G.; VAZ, R.Z.; CARDOSO, F.F. Direct and maternal breed additive and heterosis effects on growth traits of beef cattle raised in Southern Brazil. Journal of Animal Science, v.96, p.2536-2544, 2018. DOI: https://doi.org/10.1093/jas/sky160.

LEE, J.; KIM, N. Estimation of genetic variance components of body size measurements in Hanwoo (Korean cattle) using a multivariate linear model. Journal of Animal Science and Technology, v.52, p.167-174, 2010. DOI: https://doi.org/10.5187/ JAST.2010.52.3.167.

LESOSKY, M.; DUMAS, S.; CONRADIE, I.; HANDEL, I.G.; JENNINGS, A.; THUMBI, S.; TOYE, P.; BRONSVOORT, B.M de C. A live weight-heart girth relationship for accurate dosing of east African shorthorn zebu cattle. Tropical Animal Health and Production, v.45, p.311-316, 2013. DOI: https://doi.org/10.1007/ s11250-012-0220-3.

LUCILA SOBRINHO, T.; BONILHA, S.F.M.; GONÇALVES, H.C.; CASTILHOS, A.M. de; MAGNANI, E.; RAZOOK, A.G.; BRANCO, R.H. Feedlot performance, feed efficiency and carcass traits in Nellore cattle selected for postweaning weight. Revista Brasileira de Zootecnia, v.42, p.125-129, 2013. DOI: https://doi.org/10.1590/S1516-35982013000200007.

MENDONÇA, F.S.; MACNEIL, M.D.; LEAL, W.S.; AZAMBUJA, R.C.C.; RODRIGUES, P.F.; CARDOSO, F.F. Crossbreeding effects on growth and efficiency in beef cow-calf systems: evaluation of Angus, Caracu, Hereford and Nellore breed direct, maternal and heterosis effects. Translational Animal Science, v.3, p.1286-1295, 2019. DOI: https://doi.org/10.1093/tas/ txz096.

MENEZES, L.F.G. de; RESTLE, J.; BRONDANI, I.L.; ALVES FILHO, D.C.; KUSS, F.; SILVEIRA, M.F da; AMARAL, G.A. do. Características da carcaça de novilhos de gerações avançadas do cruzamento alternado entre as raças Charolês e Nelore, terminados em confinamento. Revista Brasileira de Zootecnia, v.34, p.934-945, 2005. DOI: https://doi.org/10.1590/S151635982005000300027.

MORENO, J.A. Clima do Rio Grande do Sul. Porto Alegre: Secretaria da Agricultura, 1961. 41p.

PACHECO, P.S.; RESTLE, J.; BRONDANI, I.L.; ALVES FILHO, D.C; PADUA, J.T.; MIOTTO, F.R.C. Grupo genético, sistema de acasalamento e efeitos genéticos aditivos e não-aditivos nas características de musculosidade da carcaça de novilhos oriundos do cruzamento rotativo Charolês $\times$ Nelore. Revista Brasileira de Zootecnia, v.39, p.494-502, 2010. DOI: https://doi.org/10.1590/ S1516-35982010000300007.

PACHECO, P.S.; RESTLE, J.; VAZ, F.N.; BRONDANI, I.L.; ALVES FILHO, D.C; SILVEIRA, M.F da; SEGABINAZZI, L.R.; FREITAS, L. da S.; SEVERO, M.M.; NIGELISKII, A.F. Efeitos genéticos aditivos e não aditivos, grupo genético e sistema de acasalamento nas características métricas da carcaça de novilhos oriundos do cruzamento alternado contínuo Charolês x Nelore. Semina: Ciências Agrárias, v.35, p.3319-3330, 2014. DOI: https://doi.org/10.5433/1679-0359.2014v35n6p3319.

RANDHAWA, S.S.; CHHABRA, S.; RANDHAWA, C.S.; ZAHID, U.; DHALIWAL, P.S. A note on treatment of hyperthermia in crossbred cattle. Asian Pacific Journal of Tropical Biomedicine, v.4, p.S272-S274, 2014. Suppl.1. DOI: https://doi.org/10.12980/APJTB.4.2014C179.

REZENDE, M.P.G. de; LUZ, D.F.; RAMIRES, G.G.; OLIVEIRA, N.M. de; BARBOSA FILHO, J.A.; OLIVEIRA, M.V.M. de. Caracterização zoométrica de novilhas remanescentes da raça Pantaneira. Ciência Rural, v.44, p.706-709, 2014. DOI: https://doi.org/10.1590/S0103-84782014000400022.

RODRIGUES, P.F.; MENEZES, L.M.; AZAMBUJA, R.C.C.; SUÑÉ, R.W.; SILVEIRA, I.D.B.; CARDOSO, F.F. Milk yield and composition from Angus and Angus-cross beef cows raised in Southern Brazil. Journal of Animal Science, v.92, p.2668-2676, 2014. DOI: https://doi.org/10.2527/jas.2013-705.

SAKAMOTO, L.S.; MERCADANTE, M.E.Z.; BONILHA, S.F.M.; BRANCO, R.H.; BONILHA, E.F.M.; MAGNANI, E. Prediction of retail beef yield and fat content from live animal and carcass measurements in Nellore cattle. Journal of Animal 
Science, v.92, p.5185-5193, 2014. DOI: https://doi.org/10.2527/ jas.2012-6065.

SCHIERMIESTER, L.N.; THALLMAN, R.M.; KUEHN, L.A.; KACHMAN, S.D.; SPANGLER, M.L. Estimation of breedspecific heterosis effects for birth, weaning, and yearling weight in cattle. Journal of Animal Science, v.93, p.46-52, 2015. DOI: https://doi.org/10.2527/jas.2014-8493.

SILVEIRA, D.D.; DE VARGAS, L.; ROSO, V.M.; CAMPOS, G.S.; SOUZA, F.R.P.; BOLIGON, A.A. Genetic study of visual scores and hip height at different ages in Nellore cattle. Animal Production Science, v.57, p.614-621, 2017. DOI: https://doi.org/10.1071/AN15657.

VANVANHOSSOU, S.F.U.; DIOGO, R.V.C.; DOSSA, L.H. Estimation of live bodyweight from linear body measurements and body condition score in the West African Savannah Shorthorn cattle in North-West Benin. Cogent Food \& Agriculture, v.4, 1549767, 2018. DOI: https://doi.org/10.1080/23311932.2018.1549767.

VAZ, R.Z.; RESTLE, J.; PACHECO, P.S.; VAZ; F.N.; MUEHLMANN, L.D.; ALVES FILHO, D.C.; MISSIO, R.L.;
VAZ, M.B. Genetic group and heterosis on morphometric measurements during the growth of male beef cattle. Semina: Ciências Agrárias, v.37, p.2759-2772, 2016. Supl.1. DOI: https://doi.org/10.5433/1679-0359.2016v37n4Supl1p2759.

WAKCHAURE, R.; GANGULY, S.; PRAVEEN, P.K.; SHARMA, S.; KUMAR, A.; MAHAJAN, T.; QADRI, K. Importance of heterosis in animals: a review. International Journal of Advanced Engineering Technology and Innovative Science, v.1, p.1-5, 2015.

WALMSLEY, B.J.; LEE, S.J.; PARNELL, P.F.; PITCHFORD, W.S. A review of factors influencing key biological components of maternal productivity in temperate beef cattle. Animal Production Science, v.58, p.1-19, 2016. DOI: https://doi.org/10.1071/AN12428.

WANGCHUK, K.; WANGDI, J.; MINDU, M. Comparison and reliability of techniques to estimate live cattle body weight. Journal of Applied Animal Research, v.46, 349-352, 2018. DOI: https://doi.org/10.1080/09712119.2017.1302876. 